\title{
Adiponectin, Leptin, Resistin Levels In Cystic Fibrosis Adolescents
}

M.C. Maggio Universitary Department "Materno-Infantile", University of Palermo Palermo Italy

D. Gucciardino Universitary Department "Materno-Infantile", University of Palermo Palermo Italy

M. Collura Centro Regionale per la Fibrosi Cistica, ARNAS Palermo Palermo Italy

F. Pardo Centro Regionale per la Fibrosi Cistica, ARNAS Palermo Palermo Italy

A. Liotta Universitary Department "Materno-Infantile", University of Palermo Palermo Italy

E. Gucciardino Analysis Laboratory, Children's Hospital "G. Di Cristina" Palermo Italy

S. Teresi Analysis Laboratory, Children's Hospital "G. Di Cristina" Palermo Italy

G. Corsello Universitary Department "Materno-Infantile", University of Palermo Palermo Italy

Citation: M. Maggio , D. Gucciardino, M. Collura, F. Pardo, A. Liotta , E. Gucciardino, S. Teresi, G. Corsello: Adiponectin, Leptin, Resistin Levels In Cystic Fibrosis Adolescents. The Internet Journal of Pediatrics and Neonatology. 2012 Volume 14 Number 1. DOI: 10.5580/2c28

Keywords: adiponectin, resistin, leptin, Cystic Fibrosis, adolescence

\begin{abstract}
INTRODUCTION: Patients with Cystic Fibrosis, especially in adolescence, could develop endocrine and metabolic complications, related to nutritional state and chronic inflammation. They develop a progressive decrease in lean body mass correlated with the progression of lung disease.Adipose tissue is involved as well and adipocytokines are a possible link between malnutrition and long term complications. PATIENTS AND METHODS: In 24 Cystic Fibrosis adolescents we studied auxological, nutritional, glycometabolic, endocrine patterns, together with leptin, adiponectin and resistin levels. We selected patients not affected by diabetes, insulin resistance, malnutrition, acute inflammatory states so as to avoid possible influences on the adipocytokines. RESULTS: All patients presented with an adequate BMI centile, with no statistically significant difference versus controls. HOMA IR and HOMA B\% are in the normal range but lower than in controls, expression of a lower insulin-resistance with a lower insulin secretion. Leptin is significantly higher than in controls and maintains a correlation with BMI and gender. Resistin levels are more elevated in Cystic Fibrosis than in controls, with a statistically significant direct correlation with CRP (C-reactive protein) and insulinemia T0' and T120'. Adiponectin is significantly higher in Cystic Fibrosis, inversely correlated with CRP and insulinemia and directly with cholesterol and HDL-cholesterol.CONCLUSIONS:The detection of adipocytokines levels could improve the metabolic follow-up of these patients: the maintenance of an adequate leptin gender difference is useful in the follow-up of puberty in adolescence. Adiponectin could be a marker of insulin sensitivity and prevent protein catabolism and loss of lean body mass. Resistin levels may be used as a marker of insulin resistance and may indicate the severity of chronic inflammation.This is the first study available in literature about adiponectin levels in pediatric Cystic Fibrosis patients and about resistin in Cystic Fibrosis.
\end{abstract}

\section{Introduction}

During the last few years a significant improvement in survival and quality of life, due to progress in diagnosis and follow-up, was observed in patients with Cystic Fibrosis (CF). However, since CF is characterized by weight loss, chronic negative energy balance and chronic low-grade inflammation, especially in adolescents, several complications related to endocrine and nutritional profile are described.

Long-term complications of CF include a significant decrease in lean body mass and the lean mass correlates with the progression of lung disease [1].

Leptin secretion is pulsatile and varies following a circadian rhythm; furthermore it depends on BMI and whole adipose tissue. A significant gender-dependent difference is described, with higher levels in females and significant differences during pubertal development. Caloric intake significantly influences leptin secretion and malnutrition decreases leptin levels $[2 ; 3 ; 4]$. Furthermore leptin plays an important role in energy balance and may be affected by hormonal and metabolic derangement associated with chronic disease. Serum concentrations of leptin are decreased in children with CF and associated with clinical conditions and body composition of the patients [5].

Adiponectin is principally secreted by visceral and subcutaneous adipocytes. Adiponectin has antiatherogenic and antiphlogistic properties [6]; moreover it regulates glucose and lipid metabolism, increases insulin sensitivity and ameliorates energy homeostasis. Adiponectin levels increase in conditions of negative energy balance [6]. 
Besides adiponectin levels are reduced in obesity, with a possible role in insulin resistance associated either with visceral obesity or with inflammatory diseases. Adiponectin is higher in adult CF patients than in healthy controls [7]; furthermore adiponectin is paradoxically more elevated in CF patients in adequate nutritional conditions and it is decreased in CF patients with malnutrition [8], but no data are reported in CF children. However, in a recent study CF patients showed normal levels of adiponectin despite abnormal glucose tolerance or diabetes and/or subclinical chronic inflammation [9].

In humans, resistin levels are more elevated in females (during childhood and adolescence) than in males of equivalent pubertal stage. Data about the correlation between resistin and adiposity, BMI, type 2 Diabetes Mellitus are not clear and homogeneous, even if resistin could be enhanced in chronic inflammatory diseases, thus amplifying insulin resistance. Patients with CF are possible candidates to these metabolic risks, and resistin could clarify some links between nutritional and inflammatory state and secondary diseases in CF. Furthermore no data are available in literature about resistin levels in CF.

We studied young patients with CF in order to evaluate endocrine profile, glycometabolic and insulinemic state, as well as leptin, adiponectin and resistin levels. We compared their levels with those of healthy controls, matched for age, sex, BMI and pubertal stage.

\section{Materials And Methods}

We studied 24 patients ( $14 \mathrm{M} ; 10 \mathrm{~F}$, age $13.3 \pm 2.6$ years) affected by mild CF disease, selected between all patients (72: $36 \mathrm{M} ; 36 \mathrm{~F}$ ) in peripubertal age followed by the "Regional Center for Cystic Fibrosis" of Palermo. The selection respected the following criteria:

age: $10-17$ years;

diagnosis: CF diagnosis was confirmed by pathological sweat chloride testing and genetic testing in all patients;

clinical state: during the phase of the study no acute disease was documented. We considered as signs of acute disease: fever, increase of cough and/or sputum, reduced tolerance to exercise, decline of the lung function, worsening of thorax auscultation, decrease in feeding and/or weight, increase in C-reactive protein (CRP) and sedimentation rate.

Glucose tolerance tests: patients did not present CFRD (CF related diabetes); all patients were studied with an OGTT (Oral Glucose Tolerance Test: detection of glycaemia and insulin at standardized times after $1.75 \mathrm{~g} / \mathrm{kg}$ maximum $75 \mathrm{~g}$ of oral glucose intake) and had a normal OGTT. We evaluated HOMA-IR (Homeostatic Model Assessment of Insulin-Resistance) and HOMA B\% (B-cell function) in our patients. HOMA-IR was computed as follows: fasting insulin $(\mu \mathrm{IU} / \mathrm{ml}) \times$ fasting glucose $(\mathrm{mmol} / \mathrm{ml}) / 22.5$. HOMA-B was calculated using the following formula: $20 \times$ fasting insulin $(\mu \mathrm{IU} / \mathrm{ml}) /$ fasting glucose $(\mathrm{mmol} / \mathrm{ml})$.

Treatment: neither systemic nor inhaled corticosteroids were administered to patients since a six-month period before study and in the course of study;

Furthermore CF patients did not receive lung and/or bowel transplantation and presented with an adequate nutritional status. The nutritional status was based on nutritional indexes (proteins, albumin, hemoglobin, ferritin, cholesterol, triglycerides). All the cited parameters were studied to define as adequate the nutritional condition of the patients (see table 1 ).

These patients were compared with $30(16 \mathrm{M}, 14 \mathrm{~F})$ healthy controls matched for age, sex, BMI and pubertal stage. 


\begin{tabular}{|c|c|c|c|c|}
\hline & $\begin{array}{l}\text { CF Patients } \\
\text { Control Patients }\end{array}$ & $\begin{array}{c}\text { CF Males } \\
\text { Control Males }\end{array}$ & $\begin{array}{c}\text { CF Females } \\
\text { Control Females }\end{array}$ & $p$ values \\
\hline Age & $\begin{array}{l}13.20 \pm 2.55(14.31) \\
12.50 \pm 1.72(13.80)\end{array}$ & $\begin{array}{l}12.09 \pm 2.45(13.38) \\
13.60 \pm 1.25(14.10)\end{array}$ & $\begin{array}{l}13.34 \pm 2.82(14.41) \\
12.10 \pm 1.35(12.45)\end{array}$ & $p>0.05$ \\
\hline Tanner Stage & $\begin{array}{l}(3) \\
(3)\end{array}$ & $\begin{array}{l}\text { (3) } \\
\text { (3) }\end{array}$ & $\begin{array}{l}\text { (3) } \\
\text { (3) }\end{array}$ & $p>0.05$ \\
\hline BMI (centile) & $\begin{array}{c}43.57 \pm 32.98(45.61) \\
83.5 \pm 3.5\end{array}$ & $35.63 \pm 32.44(19.87)$ & $54.70 \pm 32(59.20)$ & $p>0.05$ \\
\hline HOMA IR & $\begin{array}{c}1.17 \pm 0.718(0.895) \\
1.84 \pm 0.78(1.64)\end{array}$ & $1.219 \pm 0.624(1.015)$ & $1.103 \pm 0.863(0.88)$ & $p>0.05$ \\
\hline HОМА В\% & $\begin{array}{c}1.413 \pm 1.08(1.125) \\
2.38 \pm 1.25(2.18)\end{array}$ & $1.367 \pm 0.699(1.195)$ & $1.476 \pm 1.506(1.065)$ & $p>0.05$ \\
\hline Leptin (ng/ml) & $\begin{array}{c}8.71 \pm 10.04(5.48) \\
3.97 \pm 4.52(2.43)\end{array}$ & $\begin{array}{l}5.43 \pm 6.26(1.95) \\
2.27 \pm 1.39(2.34)\end{array}$ & $\begin{aligned} 11.66 & \pm 12.09(6.16) \\
6.16 & \pm 6.73(4.39)\end{aligned}$ & $p<0.05$ \\
\hline $\begin{array}{l}\text { Adiponectin } \\
(\mu \mathrm{g} / \mathrm{ml})\end{array}$ & $\begin{array}{l}11 \pm 3.92(11.18) \\
8.63 \pm 1.67(8.38)\end{array}$ & $\begin{array}{c}11.81 \pm 3.99(12.20) \\
7.8 \pm 1.52(7.78)\end{array}$ & $\begin{array}{c}9.86 \pm 3.73(10.23) \\
9.88 \pm 1.04(9.83)\end{array}$ & $p<0.05$ \\
\hline $\begin{array}{l}\text { Resistin } \\
(\mathrm{ng} / \mathrm{ml})\end{array}$ & $\begin{array}{l}2.05 \pm 0.89(1.68) \\
0.93 \pm 0.42(0.83)\end{array}$ & $\begin{array}{l}2.07 \pm 0.89(1.68) \\
0.93 \pm 0.29(0.98)\end{array}$ & $\begin{array}{l}2.03 \pm 0.93(1.72) \\
0.92 \pm 0.62(0.73)\end{array}$ & $\mathrm{p}<0.05$ \\
\hline
\end{tabular}

Table 1: Mean \pm standard deviation and correlations ( $p$ values) of age, Tanner Stage, BMI, HOMA IR, HOMA B\%, leptin, adiponectin and resistin levels in CF patients and in controls.

All blood samples were collected in the morning after a night fast. Adipocytokines were detected using ELISA tests (Linco Research, St Charles), and the test sensitivity was $0.5 \mathrm{ng} / \mathrm{ml}, 0.78 \mathrm{ng} / \mathrm{ml} ; 0.16 \mathrm{ng} / \mathrm{ml}$, for leptin, adiponectin and resistin respectively. TSH was detected by an immunometric assay in chemiluminescence in solid phase; T3 and T4 were detected by an immunoenzymatic assay in chemiluminescence in solid phase; cortisol, FSH and LH were detected by an immunoenzymatic assay in chemiluminescence.

The genetic study of the patients was performed identifying mutations in their CFTR gene. The mutations described were documented by performing direct sequencing analysis of the complete coding regions and flanking intronic sequences of the CFTR gene. In order to detect gene deletions or duplications that could not be identified by a direct sequencing method the foregoing analysis was followed by multiplex ligation-dependent probe amplification (MLPA) analysis.

All variables were tested for normality with the Anderson-Darling normality test, and expressed as mean \pm standard deviation ( $M \pm S D$ ). The degree of linear relationship between clinical, microbiological and biochemical parameters was calculated using Pearson product moment correlation coefficient; statistical significance was accepted at $p$ less than 0.05. Calculations were performed using MiniTAB release 14.1 Statistical Software.

\section{Results}

All patients presented with an adequate BMI centile $(43.57 \pm 32.98)$ and showed a mild gender difference (M: $35.63 \pm 32.44 ; \mathrm{F}: 54.70 \pm 32$ ), with no statistically significant difference versus healthy controls (see table 1 ).

According to international data, in our patients the more frequent genetic mutation was $\Delta \mathrm{F} 508$ : 15 patients presented with $\triangle \mathrm{F} 508$ mutation: 10 were homozygous and 5 were heterozygous, associated with other mutations; 4 patients presented with N1303K missense mutation; 3 patients presented with unknown mutations; 2 patients presented with rare mutations. Furthermore 19/24 (79\%) of the enrolled patients presented with a class II mutation ( $\triangle \mathrm{F} 508$ or $\mathrm{N} 1303 \mathrm{~K}$ ) with a consequent maturative blockage of CFTR which does not reach cell wall and is destroyed in endoplasmic reticulum.

Nutritional indexes (proteins, albumin, hemoglobin, ferritin, cholesterol, triglycerides) were studied to define as adequate the nutritional condition of the patients (see table 2 ). 


\begin{tabular}{|c|c|c|c|}
\hline & $\begin{array}{c}\text { CF Patients } \\
(\mathrm{M} \pm \mathrm{SD}) \\
\text { vs control group }\end{array}$ & $\begin{array}{c}\text { CF males } \\
(\mathrm{M} \pm \mathrm{SD}) \\
\text { vs control males }\end{array}$ & $\begin{array}{c}\text { CF females } \\
(\mathrm{M} \pm \mathrm{SD}) \\
\text { vs control females }\end{array}$ \\
\hline Total proteins $(\mathrm{gr} / \mathrm{dl})$ & $\begin{array}{c}7.13 \pm 0.70 \\
(p>0.05)\end{array}$ & $\begin{array}{c}7.01 \pm 0.73 \\
(p>0.05)\end{array}$ & $\begin{array}{c}7.32 \pm 0.66 \\
(p>0.05)\end{array}$ \\
\hline Albumin (gr/dl) & $\begin{array}{c}4.69 \pm 0.31 \\
(p>0.05)\end{array}$ & $\begin{array}{c}4.71 \pm 0.28 \\
(p>0.05)\end{array}$ & $\begin{array}{c}4.66 \pm 0.13 \\
(p>0.05)\end{array}$ \\
\hline $\mathrm{Hb}$ & $\begin{array}{c}14.01 \pm 0.94 \\
(p>0.05)\end{array}$ & $\begin{array}{c}14.11 \pm 1.11 \\
(p>0.05)\end{array}$ & $\begin{array}{c}13.86 \pm 0.59 \\
(p>0.05)\end{array}$ \\
\hline $\mathrm{Ht}$ & $\begin{array}{c}39.59 \pm 2.75 \\
(p>0.05)\end{array}$ & $\begin{array}{c}39.93 \pm 2.84 \\
(p>0.05)\end{array}$ & $\begin{array}{c}39.08 \pm 2.70 \\
(p>0.05)\end{array}$ \\
\hline Ferritin & $\begin{array}{c}40.35 \pm 17.48 \\
(\mathrm{p}>0.05)\end{array}$ & $\begin{array}{c}42.43 \pm 16.85 \\
(p>0.05)\end{array}$ & $\begin{array}{c}37.11 \pm 18.95 \\
(p>0.05)\end{array}$ \\
\hline Cholesterol & $\begin{array}{c}126.35 \pm 23.39 \\
(p>0.05)\end{array}$ & $\begin{array}{c}125.86 \pm 27.48 \\
(p>0.05)\end{array}$ & $\begin{array}{c}127.11 \pm 16.65 \\
(p>0.05)\end{array}$ \\
\hline HDL-c & $\begin{array}{c}44.67 \pm 13.21 \\
(p>0.05)\end{array}$ & $\begin{array}{c}45.91 \pm 13.55 \\
(p>0.05)\end{array}$ & $\begin{array}{c}41.25 \pm 13.45 \\
(p>0.05)\end{array}$ \\
\hline Triglycerides & $\begin{array}{c}96.96 \pm 60.6 \\
(p>0.05)\end{array}$ & $\begin{array}{c}96.90 \pm 68.2 \\
(p>0.05)\end{array}$ & $\begin{array}{c}97.00 \pm 50.4 \\
(p>0.05)\end{array}$ \\
\hline
\end{tabular}

Table 2: Mean \pm standard deviation and correlations ( $\mathrm{p}$ values) of nutritional indexes between CF patients and control group.

A statistically significant correlation between HDL and cholesterol was observed $(r=0.74 ; p=0.002)$.

CRP was in the normal range in $21 / 24$ patients, mildly positive in three, with a median value of 0.35 (n.v. $<0.5$ ). The sedimentation rate was in the normal range in all patients.

Thyroid function was studied by the detection of serum levels of TSH, fT4, T3, T4. TSH levels were $2.41 \pm 1.46$ $\mathrm{uU} / \mathrm{ml}$, with a different gender-dependent pattern of TSH levels: $1.92 \pm 0.87$ with a median of 1.92 in males, $3.24 \pm 1.93$ with a median of 3.09 in females. No significant difference of fT4, T4, T3, ACTH and cortisol levels was evidenced neither between males and females nor between CF patients and controls (see table 3 ).

\begin{tabular}{|l|c|c|c|c|c|}
\hline & $\begin{array}{c}\text { CF } \\
(\mathrm{M} \pm \mathrm{SD})\end{array}$ & $\begin{array}{c}\text { CF Males } \\
(\mathrm{M} \pm \mathrm{SD})\end{array}$ & $\begin{array}{c}\text { CF Females } \\
(\mathrm{M} \pm \mathrm{SD})\end{array}$ & Control values & $\begin{array}{c}\mathrm{p} \text {-values and } \\
\mathrm{r} \text {-values }\end{array}$ \\
\hline TSH & $2.41 \pm 1.46$ & $1.91 \pm 0.87$ & $3.24 \pm 1.92$ & $0.63-3.47$ & $\mathrm{p}>0.05 ; \mathrm{r}=-0.167$ \\
\hline T3 & $1.39 \pm 0.2$ & $1.42 \pm 0.19$ & $1.32 \pm 0.21$ & $0.8-2.0$ & $\mathrm{p}>0.05 ; \mathrm{r}=-0.375$ \\
\hline T4 & $7.77 \pm 1.55$ & $7.46 \pm 1.25$ & $8.37 \pm 2.00$ & $4.5-12.5$ & $\mathrm{p}>0.05 ; \mathrm{r}=0.179$ \\
\hline fT4 & $1.41 \pm 1.41$ & $1.35 \pm 0.17$ & $1.51 \pm 0.37$ & $0.98-2.70$ & $\mathrm{p}>0.05 ; \mathrm{r}=0.156$ \\
\hline Cortisol & $11.78 \pm 5.14$ & $11.22 \pm 4.86$ & $12.89 \pm 5.97$ & $5-25$ & $\mathrm{p}>0.05 ; \mathrm{r}=0.015$ \\
\hline ACTH & $52.25 \pm 18.58$ & $55.57 \pm 12.27$ & $47.6 \pm 26$ & $5-77$ & $\mathrm{p}>0.05 ; \mathrm{r}=0.011$ \\
\hline FSH & $4.68 \pm 2.52$ & $4.06 \pm 2.44$ & $5.83 \pm 2.44$ & $2.5-14.4$ & $\mathrm{p}>0.05 ; \mathrm{r}=0.123$ \\
\hline LH & $3.33 \pm 2.83$ & $2.56 \pm 1.55$ & $5.70 \pm 3.27$ & $1.1-11.6$ & $\mathrm{p}>0.05 ; \mathrm{r}=0.376$ \\
\hline
\end{tabular}

Table 3: Mean \pm standard deviation and correlations ( $\mathrm{p}$ values) of ACTH, cortisol, FSH, LH, thyroid hormones levels in CF patients and in controls.

ACTH and cortisol levels were in the normal range (see table 3) without any significant correlation with clinical signs and endocrine assays, except for a direct statistically significant correlation between cortisol and resistin ( $r$ $=0.5 ; p<0.01)$. HOMA IR and HOMA B\% were in the normal range but lower than in controls, expression of a lower insulin-resistance with a lower insulin secretion (see table 1). HOMA IR was inversely correlated with leptin and adiponectin; directly correlated with resistin $(r=0.358 ; p=0.086)$. HOMA B\% was inversely correlated with leptin and adiponectin, but directly correlated with resistin. No statistically significant correlation was observed between Tanner stage and insulin, glucose levels, HOMA-IR and HOMA B\% either in males or females. Leptin 
levels were significantly higher in CF $(8.71 \pm 10.04 \mathrm{ng} / \mathrm{ml}$; median: 5.48$)$ than in controls; however the physiological gender difference described in controls was also maintained and more evident in CF patients in whom leptin was significantly lower in males $(5.43 \pm 6.26)$ than in females $(11.66 \pm 12.09)$ with leptin levels significantly more elevated in CF females than in control females $(6.16 \pm 6.73)$ (see figure 1$)$.

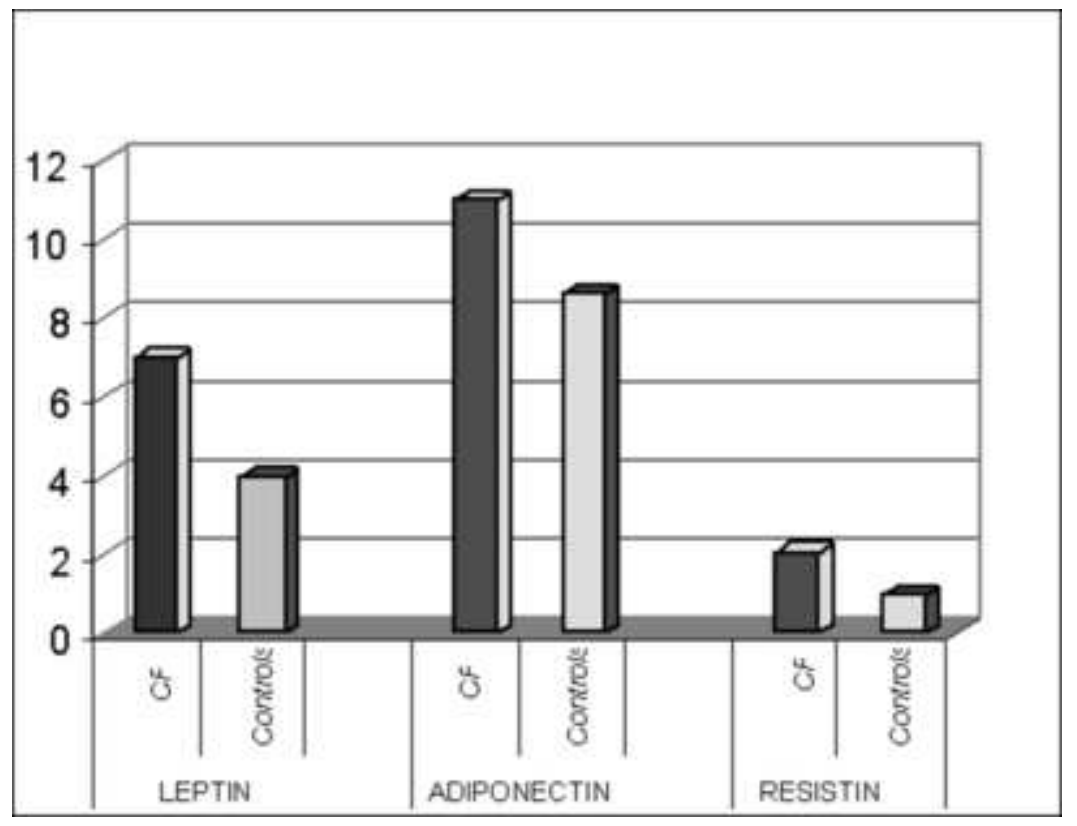

Figure 1: Leptin, adiponectin and resistin levels (median) in CF patients and healthy controls.

Leptin levels had a statistically significant correlation with BMI $(r=0.77, p=0.009)$ and ACTH $(r=-0.75 ; p=$ 0.021 ) and showed a direct correlation with insulinemia ( $\mathrm{TO}^{\prime}$ and $\mathrm{T} 120^{\prime}$ ) even if not reaching the statistical significance. No significant correlation was observed between leptin and CRP, total blood proteins, albumin, hemoglobin, ferritin, Tanner stage in males and in females. Adiponectin levels in CF were $11 \pm 3.92 \mu \mathrm{g} / \mathrm{ml}$ (median: $11.18 \mu \mathrm{g} / \mathrm{ml}$ ) higher than in controls: $8.63 \pm 1.67 \mu \mathrm{g} / \mathrm{ml}$ (median: $8.38 \mu \mathrm{g} / \mathrm{ml}$ ). In CF males adiponectin levels were $11.81 \pm 3.99$ (median: 12.20 ), higher than in controls: $7.8 \pm 1.52$ (median: 7.78);. CF females had lower adiponectin levels $9.86 \pm 3.73$ (median: 10.23) than CF males and than females controls: $9.88 \pm 1.04$ (median: 9.83) (see figure 1). No statistically significant correlation was evidenced between adiponectin and Tanner stage in males and females.

Adiponectin levels were inversely correlated with CRP, insulinemia (TO' and T120') and presented a statistically significant direct correlation with serum cholesterol $(r=0.51 ; p=0.01)$ and HDL- cholesterol $(r=0.725 ; p=$ 0.002 ). Resistin levels in CF were $2.05 \pm 0.89 \mathrm{ng} / \mathrm{ml}$ (median: $1.68 \mathrm{ng} / \mathrm{ml}$ ) significantly higher than in controls: $0.93 \pm 0.42 \mathrm{ng} / \mathrm{ml}$ (median: $0.83 \mathrm{ng} / \mathrm{ml}$ ). In CF males resistin levels were $2.07 \pm 0.89 \mathrm{ng} / \mathrm{ml}$ (median: 1.68 $\mathrm{ng} / \mathrm{ml}$ ) higher than in controls: $0.93 \pm 0.29 \mathrm{ng} / \mathrm{ml}$ (median: $0.98 \mathrm{ng} / \mathrm{ml}$ ); in CF females resistin levels were 2.03 $\pm 0.93 \mathrm{ng} / \mathrm{ml}$ (median: $1.72 \mathrm{ng} / \mathrm{ml}$ ), higher than in control females: $0.92 \pm 0.62 \mathrm{ng} / \mathrm{ml}$ (median: $0.73 \mathrm{ng} / \mathrm{ml}$ ) (see figure 1). Resistin levels showed a statistically significant correlation with: cortisol $(r=0.5 ; p<0.01)$; CRP $(r=0.81 ; p<0.001$ in the whole group; $r=0.71 ; p=0.004$ in the males group; $r=0.95 ; p<0.001$ in the females group); serum proteins $(r=0.57 ; p<0.005)$; lipids $(r=0.972 ; p=0.028)$; insulinemia T0' $(r=0.597$; $p=0.019)$ and insulinemia T120' $(r=0.674 ; p=0.012)$. No significant correlation was detected between resistin and Tanner stage either in males or in females.

\section{Discussion}

We selected 24 patients ( $14 \mathrm{M} ; 10 \mathrm{~F}$, age $13.3 \pm 2.6$ years) in peripubertal age, affected by mild CF disease without any documented acute disease during the study follow up. During the study all patients showed a normal OGTT, an adequate nutritional status and received neither steroids nor organ transplantation. We selected our patients in order to evaluate an unbiased sample of CF adolescents, without possible influences of diabetes and/or insulin resistance, malnutrition or acute inflammatory states on the adipocytokines pattern. We evaluated plasma levels of: thyroid hormones, ACTH, cortisol, FSH, LH, leptin, adiponectin and resistin and we correlated them with auxological data, nutritional indexes, glycometabolic pattern and insulin resistance. All patients had HOMA IR and HOMA B\% in the normal range, with values lower than in controls, expression of a lower insulin 
resistance with a reduced insulin secretion, possible expression of the initial endocrine pancreatic involvement. However no patients had hyperglycemic values, according to inclusion criteria.

\section{Leptin}

Leptin levels are described to be related to age, gender, caloric intake, diet composition, BMI. Leptin is reduced in subjects who follows a hypocaloric diet, independently from weight loss $[2 ; 4 ; 8]$. Our CF patients followed a hypercaloric diet although the malabsorption decreased the efficacy of the nutritional treatment on BMI and leptin levels. Leptin levels were significantly more elevated in our CF patients than in controls, linked to cytokines secretion [11]. This difference was higher in females who showed more elevated BMI. However the physiological gender difference in leptin levels was maintained in our patients. Furthermore we observed a statistically significant correlation with FSH and HDL-cholesterol. The maintenance of a statistically significant correlation with FSH levels emphasizes the role of leptin on puberty and on the physiological regulation of hypophyseal secretion in patients with a good clinical outcome. Higher leptin levels in CF could be secondary to immunological hits and IL6 and TNF alpha secretion. Moreover leukocyte cytokines could contribute to the poor growth and the hypercatabolic state typical of these patients [11].

\section{Adiponectin}

Adiponectin is considered as a marker of insulin sensitivity, with decreased levels in obesity, inflammatory states and in insulin-resistant patients $[9 ; 12]$. Other studies demonstrated higher adiponectin levels in well nourished adult CF patients than in healthy controls $[7 ; 8 ; 9]$ and normal adiponectin levels in CF with diabetes or impaired glucose tolerance and/or positive inflammatory markers [9]. Adiponectin levels were mildly higher in our adolescents than in controls, linked to the low malnutrition state typically present in CF. This difference was described in CF males but not in CF females, linked to the higher BMI. In our patients we found a significant correlation between insulin-resistance indexes and adipocytokines: adiponectin was inversely correlated with insulin, HOMA IR and HOMA B\%, as previously described in obese children [7]. Higher adiponectin levels preserved our adolescents, patients at risk of severe malnutrition [8], from insulin resistance and lean body mass decrease. Moreover these are the first data available about adiponectin levels in pediatric CF patients.

\section{Resistin}

The data reported in literature about resistin levels are controversial, both in correlation with BMI and with the progression of puberty; however inflammatory cytochines increase resistin levels [13]. In our patients resistin levels were more elevated than in controls and showed a significant direct correlation with CRP. Nevertheless resistin increase may be the effect of chronic inflammatory pattern typical of CF [9]. Similarly in patients with chronic kidney disease [14] and in critically ill patients serum resistin is correlated to inflammatory markers as CRP [15]. A statistically significant direct correlation with cortisol was also observed in our patients: this datum is original and possible linked to the positive correlation with CRP. In fact cortisol is a marker of chronic stress and has a statistically significant direct correlation with CRP $(r=0.505 ; p=0.033)$. Furthermore resistin is directly correlated with HOMA IR and has a statistically significant correlation with insulinemia (T0' and T120').

Despite the reputation of $\mathrm{CF}$ as a progressive, lethal disease, proper management of the full spectrum of CF-related endocrine disorders offers major opportunities to reduce morbidity and improve quality of life. The detection of adipocytokines levels could improve the metabolic follow-up of these patients: the maintenance of adequate leptin gender difference is useful in the follow-up of puberty in adolescence. Adiponectin could be a marker of insulin sensitivity. Furthermore it could prevent protein catabolism and lean body mass drop. Resistin correlates with insulin resistance and with the severity of chronic inflammation. Our findings emphasize the need for a comprehensive endocrine and metabolic evaluation and a long-term follow-up in patients with CF.

\section{References}

1. Bolton CE, Ionescu AA, Nixon LS, Luzio S, Lewis-Jenkins V, Evans WD, Stone MD, Owens DR, Routledge PA, Shale DJ: Pulmonary function, body composition, and protein catabolism in adults with cystic fibrosis. Am J Respir Crit Care Med; 2002; 165: 495-500.

2. Garcia-Mayor RV, Andrade MA, Rios M, Lage M, Dieguez C, Casanueva FF: Serum leptin levels in normal children: relationship to age, gender, body mass index, pituitary-gonadal hormones, and pubertal stage. J Clin Endocrinol Metab; 1997; 82:2849-2855.

3. Havel PJ, Kasim-Karakas S, Dubuc GR, Mueller W, Phinney SD: Gender differences in plasma leptin concentrations. Nat Med; 1996; 2:949-950.

4. Mann DR, Abiodun O. K. Johnson, Terry G, Castracane VD: Changes in circulating leptin, leptin receptor and gonadal hormones from infancy until advanced age in humans. J of Clin Endocrinol Metab; 2003; 88(7):3339-3345.

5. Boguszewski MC, Kamoi TO, Bento Radominski R, Boguszewski CL, Rosberg S, Filho NA, Sandrini Neto R, Albertsson-Wikland $\mathrm{K}$. Insulin-like growth factor-1, leptin, body composition, and clinical status interactions in 
children with cystic fibrosis. Horm Res. 2007;67(5):250-6.

6. Lihn AS, Bruun JM, He G, Pedersen SB, Jensen PF, Richelsen B: Lower expression of adiponectin mRNA in visceral adipose tissue in lean and obese subjects. Mol Cell Endocrinol; 2004; 219: 9-15.

7. Moriconi N, Kraenzlin M, Müller B, Keller U, Nusbaumer CPG, Stöhr S, Tamm M, Puder JJ: Body composition and adiponectin serum concentrations in adult patients with cystic fibrosis. J Clin Endocrinol Metab; 2006; 91(4): 1586-1590.

8. Panagopoulou P, Fotoulaki M, Manolitsas A, Pavlitou-Tsiontsi E, Tsitouridis I, Nousia-Arvanitakis S: Adiponectin and body composition in cystic fibrosis. J Cyst Fibros; 2008; 7(3): 244-251.

9. Hammana I, Malet A, Costa M, Brochiero E, Berthiaume Y, Potvin S, Chiasson JL, Coderre L, Rabasa-Lhoret R: Normal adiponectin levels despite abnormal glucose tolerance (or diabetes) and inflammation in adult patients with cystic fibrosis. Diabetes metab; 2007; 33(3): 213-219.

10. Fantuzzi G: Adiponectin and inflammation: consensus and controversy. J Allergy Clin Immunol; 2008; 121(2): 326-330.

11. Ahme ML, Ong KK, Thomson AH, Dunger DB: Reduced gains in fat and fat-free mass, and elevated leptin levels in children and adolescents with cystic fibrosis. Acta Paediatr; 2004; 93(9): 1185-1191.

12. Gil-Campos M, Canete R, Gil A: Hormones regulating lipid metabolism and plasma lipids in childhood obesity. Int J Obes Relat Metab Disord; 2004; 28s3: s75-80.

13. Gerber M, Boettner A, Seidel B, Lammert A, Bar J, Schuster E, Thiery J, Kiess W, Kratzsch J: Serum Resistin Levels of Obese and Lean Children and Adolescents: Biochemical Analysis and Clinical Relevance. J Clin Endocrinol Metab; 2005; 90(8):4503-4509.

14. Axelsson J, Bergsten A, Qureshi AR, Heimbürger $O$, Bàràny $P$, Lönnqvist $F$, Lindholm $B$, Nordfors $L$, Alvestrand A, Stenvinkel P: Elevated resistin levels in chronic kidney disease are associated with decreased glomerular filtration rate and inflammation, but not with insulin resistance. Kidney Int; 2006; 69(3): 596-604.

15. Koch A, Gressner OA, Sanson E, Tacke F, Trautwein C: Serum resistin levels in critically ill patients are associated with inflammation, organ dysfunction and metabolism and may predict survival of non-septic patients. Crit. Care; 2009; 13(3):R95.

Generated at: Sat, 25 May 2013 12:06:18 -0500 (00002c28) - http://archive.ispub.com:80/journal /the-internet-journal-of-pediatrics-and-neonatology/volume-14-number-1/adiponectin-leptin-resistin-levelsin-cystic-fibrosis-adolescents.html 